\title{
Movement and foraging behavior of short-finned pilot whales in the Mid-Atlantic Bight: importance of bathymetric features and implications for management
}

\author{
Lesley H. Thorne ${ }^{1, *}$, Heather J. Foley ${ }^{2}$, Robin W. Baird ${ }^{3}$, Daniel L. Webster ${ }^{3}$, \\ Zachary T. Swaim², Andrew J. Read ${ }^{2}$
}

${ }^{1}$ School of Marine and Atmospheric Sciences, Stony Brook University, Stony Brook, NY 11790, USA

${ }^{2}$ Duke University Marine Laboratory, Duke University, 135 Duke Marine Lab Road, Beaufort, NC 28516, USA

${ }^{3}$ Cascadia Research Collective, 218 1/2 West 4th Avenue, Olympia, WA 98501, USA

\begin{abstract}
Shelf break systems are ecologically important regions of the ocean, and are often characterized by enhanced productivity and high densities of species from lower to upper trophic levels. Along with associated submarine canyons, shelf break regions provide important foraging habitat for deep-diving odontocetes such as pilot whales. Short-finned pilot whales Globicephala macrorhynchus are found throughout tropical and subtropical waters, but there is little information on the habitat use of this species in the northwest Atlantic. We examined the movements and foraging behavior of short-finned pilot whales using data from satellite tags $(\mathrm{n}=33)$ deployed off Cape Hatteras, North Carolina, USA in 2014 and 2015. Pilot whale tracks ranged from Cape Lookout, North Carolina north to Georges Bank, with movements and habitat use primarily focused north of Cape Hatteras. We observed 2 distinct modes of behavior, with most pilot whales showing a strong affinity for the continental shelf break and others following offshore meanders of the Gulf Stream for all or part of the observed track. We used first passage time (FPT) to assess arearestricted search behavior, and found that FPT was significantly higher close to the shelf break and in submarine canyons. Our results demonstrate the importance of steep bathymetric features to the foraging habitat and distribution of short-finned pilot whales in this region. In addition, our findings suggest that pilot whales in the Mid-Atlantic Bight may have developed specialized foraging behaviors for targeting steep bathymetric gradients, and that their latitudinal distribution may be limited to regions where this foraging strategy is effective.
\end{abstract}

KEY WORDS: Pilot whale - Foraging behavior - Shelf break - Submarine canyon · Gulf Stream · Distribution · First passage time

\section{INTRODUCTION}

The presence of steep bathymetric slopes along the continental shelf break has strong influences on physical oceanography and biological productivity, and as such, shelf break systems are important regions of trophic transfer (Acha et al. 2004, Genin 2004, Yen et al. 2004, Ryan et al. 2005, He et al. 2011, Hazen et al. 2013). Enhanced productivity in shelf

${ }^{*}$ Corresponding author: lesley.thorne@stonybrook.edu break regions both aggregates and attracts lowerand mid-trophic level species (Herman et al. 1981, Munk et al. 1995, Mackas et al. 1997, Young et al. 2001, Colloca et al. 2004, Genin 2004). The resulting increase in prey densities at these fixed locations creates persistent and predictable foraging areas for marine predators, and notably for air-breathing predators whose prey can be aggregated or advected into shallower, more accessible waters (Waring et al.

(C) The authors 2017. Open Access under Creative Commons by Attribution Licence. Use, distribution and reproduction are unrestricted. Authors and original publication must be credited. 
2001, Yen et al. 2004, Freeman et al. 2010, Okkonen et al. 2011). In particular, submarine canyons along the shelf break have steep and complex bathymetry and create foraging habitat for deep-diving odontocetes such as sperm whales and beaked whales (e.g. Hooker et al. 1999, Waring et al. 2001, Moors-Murphy 2014). Examining the habitat use of marine predators within shelf break systems is necessary to understand the impact of these systems on food web dynamics in pelagic ecosystems. While the influence of shelf break systems on the abundance and distribution of marine predators has been well documented (Springer et al. 1996, Catard et al. 2000, Waring et al. 2001, Yen et al. 2004, Suryan et al. 2006, Freeman et al. 2010), fewer studies have analyzed animal movement to elucidate how shelf break regions influence foraging behavior specifically (Suryan et al. 2006).

Pilot whales Globicephala spp. are deep-diving odontocetes that occur in shelf break regions and forage at depths of $>800 \mathrm{~m}$ (Baird et al. 2002, Heide-Jørgensen et al. 2002, Garrison 2007, Aguilar Soto et al. 2008, Jensen et al. 2011, Baird 2016, Quick et al. 2017). Information on the spatial habitat use of pilot whales in the northwest Atlantic is limited and, until recently, most information on their habitat use in this region was derived from shipboard and aerial surveys (although see Mate et al. 2005). Like many marine mammals, pilot whales use habitats over large spatial and temporal scales (e.g. Lewison et al. 2004, Moore 2008), making it difficult to understand patterns of movement from survey data alone. Furthermore, 2 species of pilot whale exist in the northwest Atlantic: short-finned (G. macrorhynchus) and longfinned (G. melas) pilot whales. These 2 species are difficult to distinguish reliably at sea, except with close approaches under ideal conditions (Rone \& Pace 2012). The 2 species are believed to differ in their ecology and habitat use (Gannon et al. 1997, Mintzer et al. 2008, Hayes et al. 2017), but our understanding of their individual distribution, habitat use, and demography is incomplete (Hayes et al. 2017).

In the northwest Atlantic, short-finned pilot whales typically occur in subtropical and tropical waters while long-finned pilot whales are distributed further north in boreal waters, but the limits of their ranges and the area of overlap remain unclear. Long-finned pilot whales occur from Norway to New Jersey (Abend \& Smith 1999, Taylor et al. 2008, Hayes et al. 2017). Short-finned pilot whales are thought to range from the southern end of Georges Bank south into the tropics (Taylor et al. 2011, Hayes et al. 2017). The 2 species likely overlap along the shelf break be- tween New Jersey and Georges Bank, but information on the spatial and seasonal distribution of both species is limited (Hayes et al. 2017). In the United States, the respective distributions of short-finned and long-finned pilot whales are estimated by confirming species identity with biopsy samples and modeling these observations in relation to sea surface temperature (SST). Abundance estimates from shipboard surveys are then partitioned by species using the probability of each species' occurrence based on SST (Hayes et al. 2017). Most pilot whale sightings can be attributed to a species using this approach, but the sightings represent only a snapshot in time and space of each species' habitat use and may not reflect the dynamic nature of the ranges of these species. Detailed information on speciesspecific habitat use is required to develop a more precise understanding of the distribution of both species and their overlap.

In addition, a better understanding of patterns of movement, habitat use, and behavior is necessary in order to generate a full assessment of the threats faced by these species. Off the US Atlantic coast, short-finned pilot whales interact with a pelagic longline fishery for swordfish and tuna (Garrison 2007). As a result of interactions with the pelagic longline fishery, entanglements resulting in mortality and serious injury (M/SI) are relatively common; the short-finned pilot whale is the most frequently taken marine mammal species in this fishery (Garrison 2007). Under the US Marine Mammal Protection Act, if M/SI exceeds sustainable levels, estimated as the potential biological removal (PBR) level, fishermen, scientists, and managers must work together to develop strategies to reduce takes to below PBR. The total annual estimated fishery-related M/SI of shortfinned pilot whales in the pelagic longline fishery recently exceeded PBR for this stock (Hayes et al. 2017). With our current level of understanding of pilot whale habitat use, it is difficult to develop effective management strategies for the species. An improved understanding would provide managers with knowledge regarding where the risk of pilot whalelongline interactions is greatest. Observations of short-finned pilot whale bycatch in the pelagic longline fishery have suggested that they occur in proximity to the deep slope waters of the continental shelf within the Mid-Atlantic Bight (MAB) (Garrison 2007), but the influence of the shelf break and submarine canyons on pilot whale foraging behavior has not been investigated to date.

Foraging behaviors of marine mammals can be developed through social learning (Rendell \& White- 
head 2001), and as a result, marine mammals can show a great deal of intraspecific variability in foraging behavior (e.g. Baird \& Dill 1995, Nowacek 2002, Estes et al. 2003, Sargeant et al. 2005). In addition, animals respond to spatial heterogeneity in resources, and foraging behavior can be focused at different spatial scales (Fauchald 1999, Pinaud \& Weimerskirch 2005). Thus, to understand patterns of pilot whale foraging behavior relative to environmental features, it is important to account for both individual effects and to control for the spatial scales at which animals interact with their environment (Levin 1992, Pinaud \& Weimerskirch 2005).

The objectives of the present study were to (1) describe the movements and scales of foraging behavior for individual satellite-tagged short-finned pilot whales in the MAB, and (2) investigate how their patterns of habitat use and foraging behavior are influenced by bathymetric features. tags were programmed to transmit data daily for the first $60 \mathrm{~d}$ of the deployment, every 3rd day for the subsequent $21 \mathrm{~d}$, and every 5th day for the remainder of the deployment. In addition, we deployed Mk10-A satellite-linked depth-recording tags (Wildlife Computers) on 8 short-finned pilot whales. Mk10 tags were programmed to transmit data daily for the first $20 \mathrm{~d}$ of the deployment, every third day for the subsequent $30 \mathrm{~d}$, and every ninth day for the remainder of the deployment. Tags were remotely deployed into the dorsal fin or base of the dorsal fin using a pneumatic projector and attached with two $6.8 \mathrm{~cm}$ titanium darts with backward-facing petals. Tags were deployed in both the spring and fall of 2014 and 2015, and tag transmissions through the first week of January 2016 were included in the analysis. Tag data used in analyses covered the months of May through the end of December in 2014, and May 2015 through early January 2016 (see Table 1). Two tags transmit-

\section{MATERIALS AND METHODS}

\section{Study area}

The continental shelf break in the MAB is characterized by steep bathymetric relief between depths of 200 and $1000 \mathrm{~m}$ (Fig. 1). A series of submarine canyons are located along the shelf break, extending from waters offshore of Norfolk, Virginia north to the Gulf of Maine. North of Cape Hatteras, North Carolina, the Gulf Stream separates from the continental shelf and flows northeast, and the location of the Gulf Stream and associated Gulf Stream warm core rings strongly impact the oceanography and ecology of organisms in the MAB (e.g. Planque \& Taylor 1998, Conversi et al. 2001, Borkman \& Smayda 2009, Nye et al. 2011).

\section{Satellite telemetry}

We deployed 29 Wildlife Computer SPOT5 tags in the Low Impact Minimally Percutaneous External-electronics Transmitter (LIMPET) configuration on short-finned pilot whales Globicephala macrorhynchus off Cape Hatteras in 2014 and 2015 (Fig. 1). The

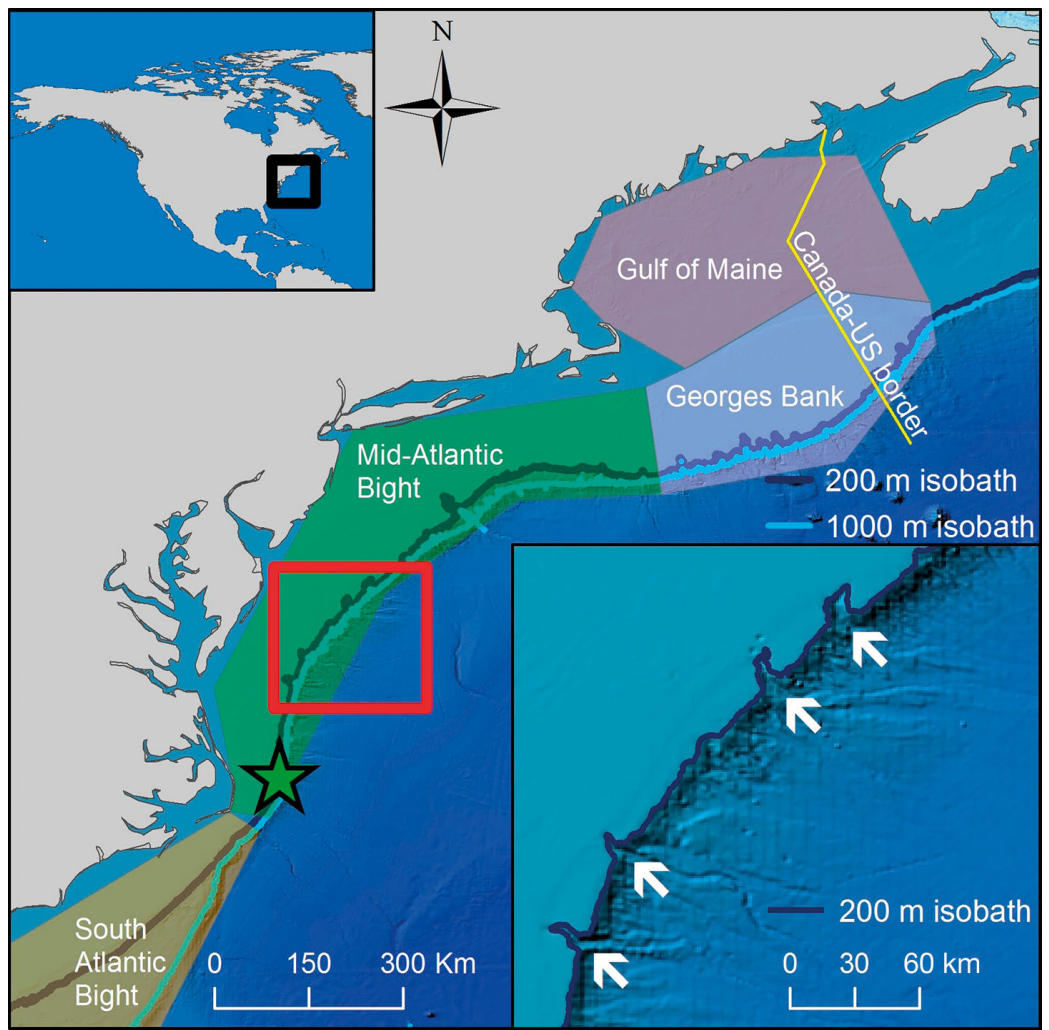

Fig. 1. Bathymetric relief and regional designations. Upper-left inset: Black square indicates the study area in North America. Lower-right inset is a zoomin of the area marked by the red square and highlights submarine canyons (indicated with arrows, from lower left to top right: Norfolk Canyon, Washington Canyon, Baltimore Canyon, and Wilmington Canyon) relative to the $200 \mathrm{~m}$ isobath. Green star: Globicephala macrorhynchus tagging location off of Cape Hatteras, North Carolina. Regional designations follow those used by the US Northeast Fisheries Science Center (e.g. Fratantoni et al. 2015) 
ted locations for $<1 \mathrm{~d}$ and were excluded from analyses. In 4 cases, tags were deployed on pairs of pilot whales from the same social group that showed similar patterns of movement over the course of their tracks. We therefore removed the shorter track of each pair from analyses to avoid pseudoreplication, resulting in a sample size of 33 tags. Tag data were processed with the Douglas Argos-Filter to remove erroneous location estimates (Douglas et al. 2012; user-defined settings: maximum rate of movements = $15 \mathrm{~km} \mathrm{~h}^{-1}$, maximum redundant distance $=3 \mathrm{~km}$, default rate coefficient for marine mammals $=25$, location classes 2 and 3 retained). Filtered data were used to produce $75 \%$ and $95 \%$ kernel density estimates (KDEs) in the Geospatial Modelling Environment (www.spatialecology.com/gme/) to represent habitats frequently used by pilot whales (e.g. Cianfrani et al. 2011, Pendoley et al. 2014, Mei et al. 2017).

\section{Environmental data}

A close relationship between pilot whale movements and both shelf break and canyon features was apparent during our exploratory data analysis. To assess the influence of these features on pilot whale foraging behavior, we used the $200 \mathrm{~m}$ isobath, generated from GEBCO bathymetric grids (30 arc-second resolution; www.gebco.net/data_and_products/gridded_ bathymetry_data/), as a proxy for the location of the shelf break. Short-finned pilot whales typically forage at depths of 200-1000 m in our study area (Quick et al. 2017), so consequently we identified canyons by examining valleys in the continental shelf slope that were evident in both the $200 \mathrm{~m}$ and $1000 \mathrm{~m}$ isobaths. We defined canyons as deep, steep-sided valleys that extended into the continental shelf for $>5 \mathrm{~km}$ in the cross-shelf direction of the $200 \mathrm{~m}$ isobath (Fig. 1, lower-right inset).

\section{Environmental effects on foraging behavior}

We used first passage time (FPT) to evaluate pilot whale foraging behavior. FPT is a scale-dependent metric used to indicate how much time an animal spends in a given area along its path of movement (Fauchald \& Tveraa 2003, Kappes et al. 2010). FPT can be calculated across a range of scales for each animal's path to identify the spatial extent of arearestricted search (ARS) for that individual (Suryan et al. 2006, Robinson et al. 2007). ARS behavior, demonstrated by decreased speed and increased turning rates, is often used to restrict movements to areas of increased resource density (Curio 1976, Kareiva \& Odell 1987). Thus, FPT can be used to indicate foraging behavior along an animal's track, with regions of high FPT representing intensive foraging behavior (Kappes et al. 2010). The extent of the ARS can be identified from FPT by identifying the scale at which there is a peak in the variance of log-transformed FPT (Fauchald \& Tveraa 2003).

We restricted our analysis of FPT to initial periods of each track with daily satellite transmissions, because duty-cycled data may influence the apparent spatial scale of the ARS. We calculated FPT at spatial scales of $2-150 \mathrm{~km}$ at increments of $2 \mathrm{~km}$ and identified the ARS scale for each individual. To compare FPT among individuals, we then scaled FPT by the spatial scale of the ARS (FPT divided by the area of a circle whose radius is the ARS scale; Kappes et al. 2010). We used the approach of Suryan et al. (2006) to reduce spatial autocorrelation in FPT data. Briefly, we identified the location with the maximum FPT value (representing the most intensively searched area) within the ARS radius, excluded all other locations within $2 \times$ the ARS radius of that location to exclude locations with overlapping radii, and then selected the location with the maximum FPT from the remaining locations. Following exploratory analyses, we assessed differences in FPT close (less than the median distance of $4500 \mathrm{~m}$ ) vs. far (greater than the median value) from the shelf break and within vs. outside of canyons, using nested ranks tests with 10000 bootstrap iterations. Ranks tests are mixed-model extensions of the Wilcoxon test in which treatment (distance to shelf break, inside or outside canyons) is a fixed effect and group membership (individual) is a random effect. We restricted the sample for the nested ranks test to individuals tracked in regions both close and far from the shelf break $(\mathrm{n}=$ 18 ) and inside and outside canyons $(n=14)$. Lastly, we examined locations of maximum FPT on a weekly basis to investigate broader relationships of foraging effort with bathymetry. FPT analyses were conducted in the R statistical package (version 3.1.2) using the adehabitatLT (version 0.3.20) and the nestedRanksTest (version 0.1) libraries.

\section{RESULTS}

\section{Patterns of habitat use}

Tagged pilot whales were highly mobile, traveling 192-7879 km (mean: $2758 \mathrm{~km}$ ), and extending 50$1314 \mathrm{~km}$ (mean: $356 \mathrm{~km}$ ) from the tagging location, 


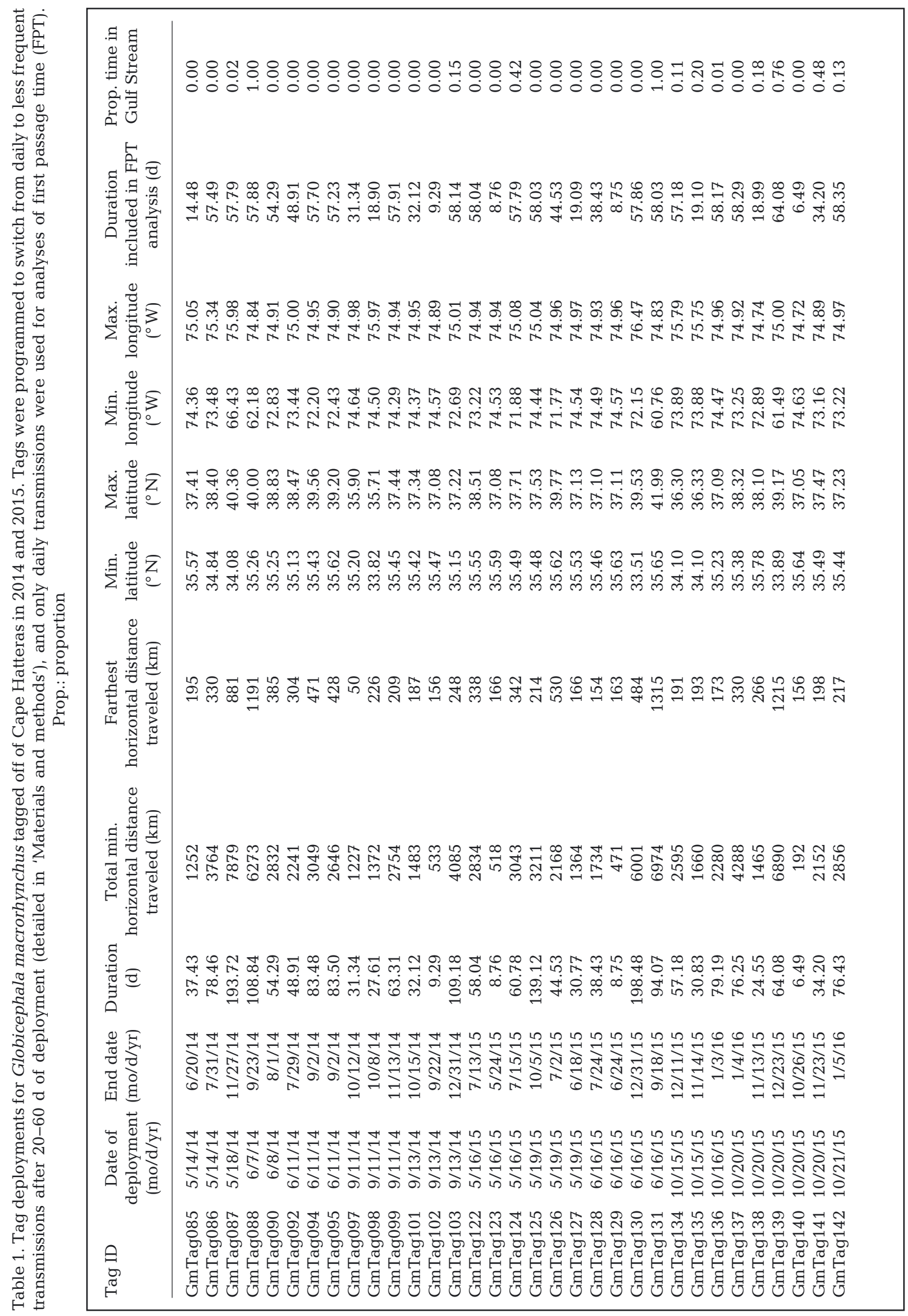




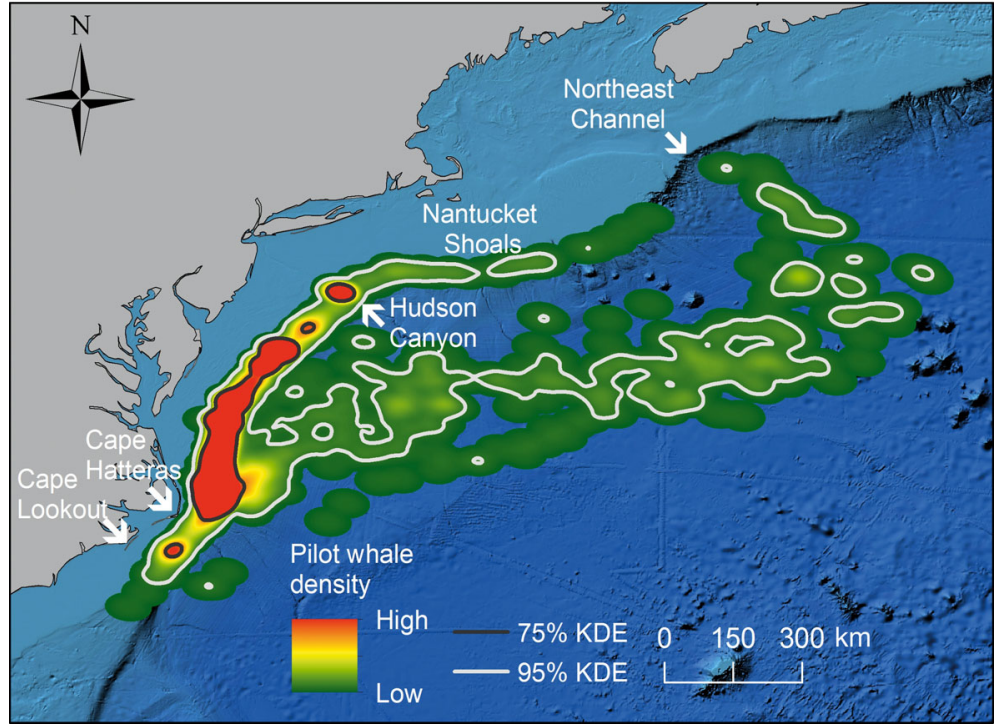

Fig. 2. Density of Globicephala macrorhynchus tracks and $75 \%$ and $95 \%$ kernel density estimates (KDEs) relative to bathymetric relief during tag deployments that ranged from 6 to $198 \mathrm{~d}$ (mean: $61 \mathrm{~d}$; Table 1). Most tagged whales moved north of Cape Hatteras (Fig. 2); however, 3 pilot whales ventured south of Cape Hatteras, and 1 was documented south of Cape Lookout, North Carolina on a single day in November 2015. The highest densities of pilot whale locations occurred along the shelf break from Cape Hatteras to Hudson Canyon, and the $95 \% \mathrm{KDE}$ of pilot whale distribution extended south to shelf break waters south of Cape Lookout, north into shelf break waters of Nantucket Shoals, and included Gulf Stream waters north and east of Cape Hatteras.

Our tagged pilot whales showed 2 distinct modes of habitat use, targeting areas adjacent to the continental shelf break or associating with offshore Gulf Stream wa- a

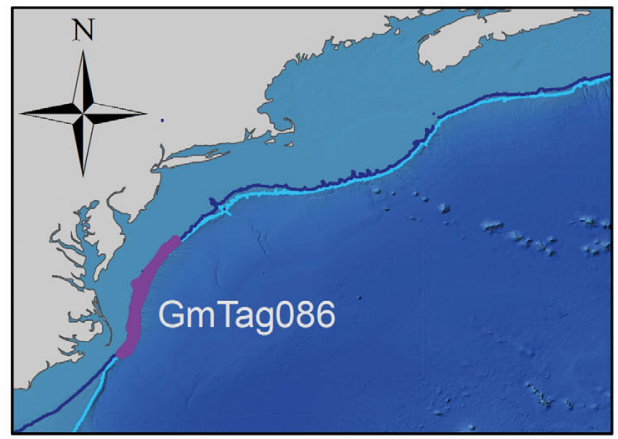

b

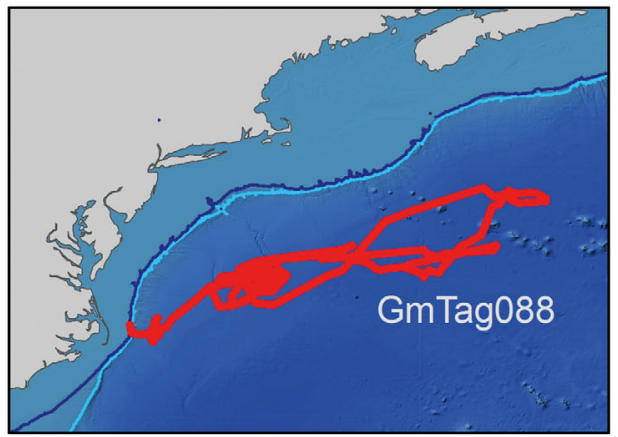

c

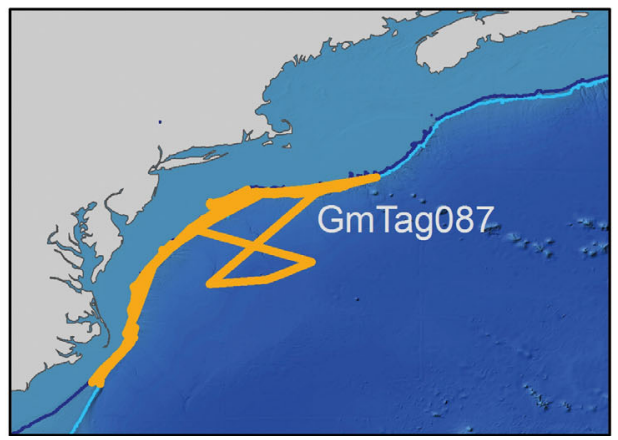

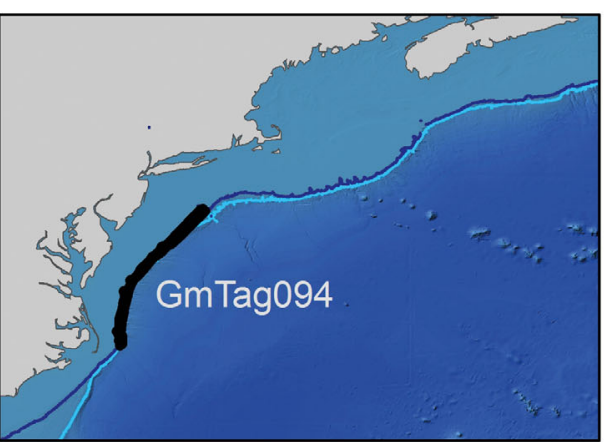
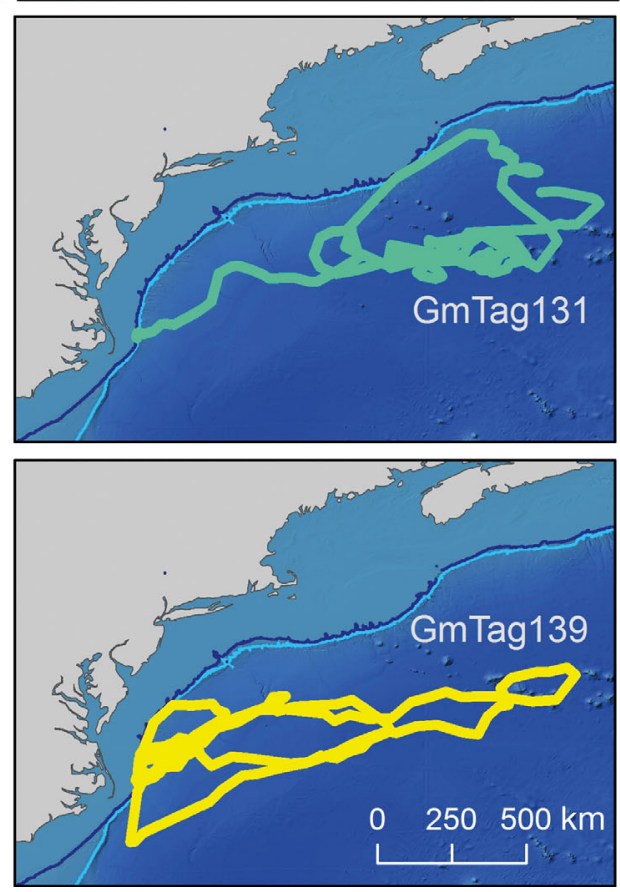

$-200 \mathrm{~m}$ isobath
$1000 \mathrm{~m}$ isobath

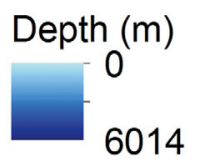

Fig. 3. Examples of Globicephala macrorhynchus tracks relative to bathymetry, highlighting individuals (see Table 1 for tag IDs) using (a) shelf break waters, (b) Gulf Stream waters, and (c) both shelf break and Gulf Stream waters 
ters, with some individuals using both habitats (Fig. 3). Most animals were associated with the shelf break for much or all of their track. More than $75 \%$ of all locations occurred within $10 \mathrm{~km}$ of the shelf break and more than half ( $57 \%$ ) occurred within $5 \mathrm{~km}$ of the shelf break. Pilot whales that were associated with
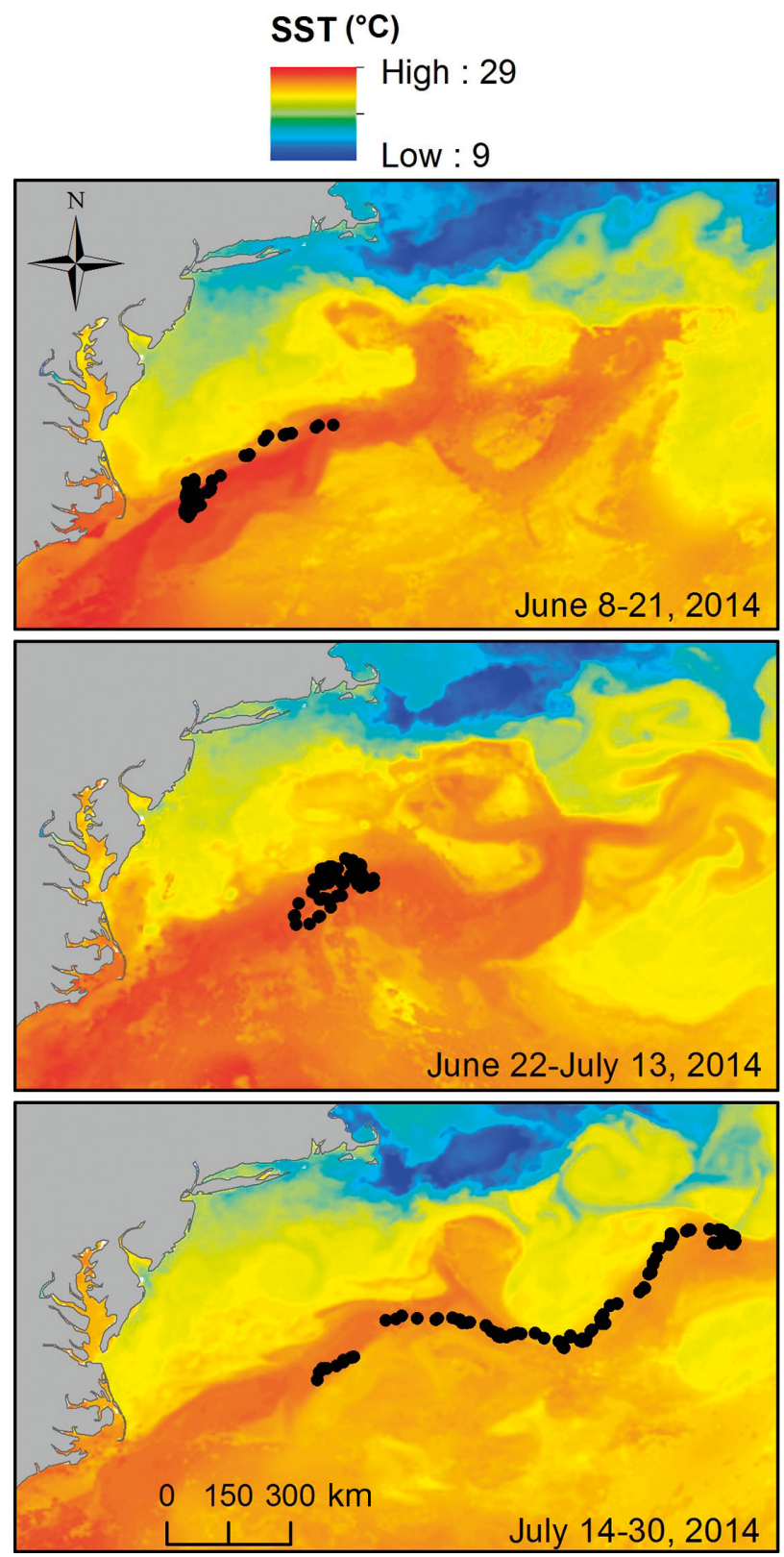

Fig. 4. Sequential locations of an individual satellite-tagged Globicephala macrorhynchus (GmTag088; see Table 1) in the Gulf Stream in June and July 2014. Only the outbound portion of the track is shown to highlight the close relationship between pilot whale movements and Gulf Stream features. Sea surface temperatures (SSTs) shown are daily Level 4 Group for High Resolution Sea Surface Temperature (GHRSST) SST data from June 15, June 30, and July 22, respectively the shelf break moved back and forth along the shelf break repeatedly. This behavior was observed in all months in which tags were transmitting (Figs. S1 \& S2 in the Supplement at www.int-res.com/articles/suppl/ m584p245_supp.pdf). Twelve pilot whales were associated with offshore Gulf Stream waters for some portion of their track. Of these animals, 3 were observed in offshore Gulf Stream waters for more than half of their track (Table 1), closely following Gulf Stream meanders into distant offshore waters (Fig. 4); the others spent shorter periods in Gulf Stream waters before returning to the shelf break.

\section{Area-restricted foraging behavior}

All tagged pilot whales showed ARS behavior, but there was considerable variability in the scale of their ARS (Fig. 5). ARS scales varied from 2 to $148 \mathrm{~km}$ (mean: $24 \mathrm{~km}$ ), with 27 of 31 tracks showing an ARS scale of $40 \mathrm{~km}$ or less. Due to the limited sample of animals that associated with the Gulf Stream during daily satellite transmissions, we focused our analysis of FPT on tagged whales showing the shelf breakassociated foraging pattern. FPT was significantly higher close to the shelf break (nested ranks test, $\mathrm{p}=$ 0.0004 ) and within submarine canyons (nested ranks test, $\mathrm{p}=0.0001$ ), reflecting higher foraging effort in these regions (Fig. 6). Analyses of high FPT along individual tracks and maximum FPT for each individual on a weekly basis further highlighted the importance of submarine canyons to their foraging habitat (Fig. 7, Fig. S3 in the Supplement).

\section{DISCUSSION}

Our analyses demonstrate that the continental shelf break provides important foraging habitat for short-finned pilot whales in the northwest Atlantic. Most of the tagged pilot whales in this study focused their foraging efforts close to the shelf break, and long-duration tag deployments on pilot whales that foraged in the Gulf Stream indicated that these animals returned to forage on the shelf break following excursions into offshore Gulf Stream waters. The biological effects of ocean currents interacting with steep slopes along the continental shelf break likely carry up to these upper trophic level species by aggregating prey species and/or by making prey more accessible, thus highlighting the importance of biophysical coupling and trophic transfer in shelf break ecosystems. 

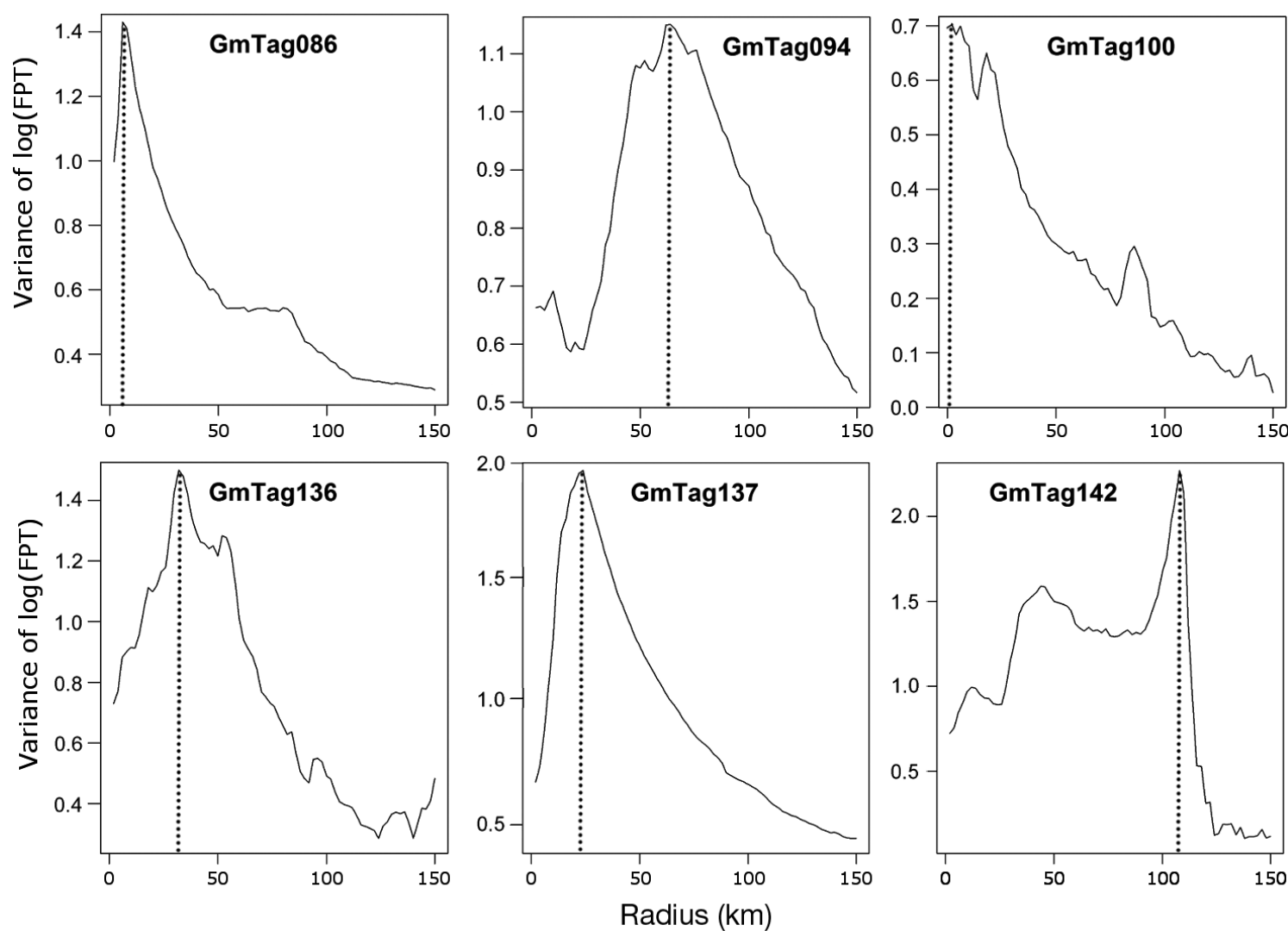

Fig. 5. Examples of variance in $\log (\mathrm{FPT})$ as a function of radius for Globicephala macrorhynchus telemetry tracks (see Table 1 for tag IDs). Peak in variance was used to indicate scale of the area-restricted search (dashed line). FPT: first passage time.

GmTag 100 was not included in the final analysis
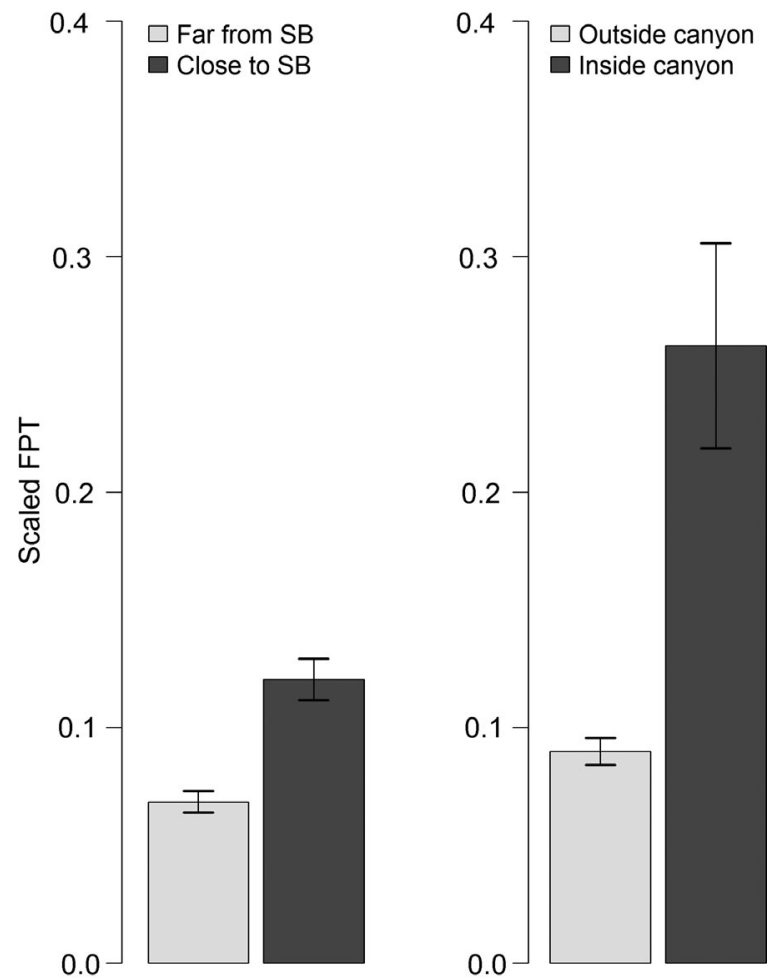

Our results have implications for stock structure and management of short-finned pilot whales. In the US Atlantic exclusive economic zone (EEZ), the species is managed as a single stock that ranges from Florida to New England (Hayes et al. 2017). Despite the extensive northward movements of whales tagged off Cape Hatteras, we were surprised that none of the tagged whales moved further south into the South Atlantic Bight (SAB). We hypothesize that shelf break waters off of Cape Lookout may act as a biogeographic boundary that could influence the stock structure of short-finned pilot whales. Further, we postulate that the use of shelf break habitats by short-finned pilot whales in the MAB may play a role in limiting the distribution of these animals to waters

Fig. 6. Scaled first passage time (FPT) of Globicephala macrorhynchus relative to proximity to shelf break $\left(\mathrm{SB}_{\text {; }}\right.$ close: $<4.5 \mathrm{~km}$ from $200 \mathrm{~m}$ isobath, far: $>4.5 \mathrm{~km}$ from $200 \mathrm{~m}$ isobath) and occurrence within submarine canyons (mean \pm $\mathrm{SE}$ ). Units of scaled FPT are $\mathrm{h} \mathrm{km}^{-2}$; e.g. FPT of $30 \mathrm{~h}$ within a $6 \mathrm{~km}$ area-restricted search radius would result in a scaled FPT of 0.27 ( $30 \mathrm{~h}$ divided by the area of a $6 \mathrm{~km}$-radius circle) 


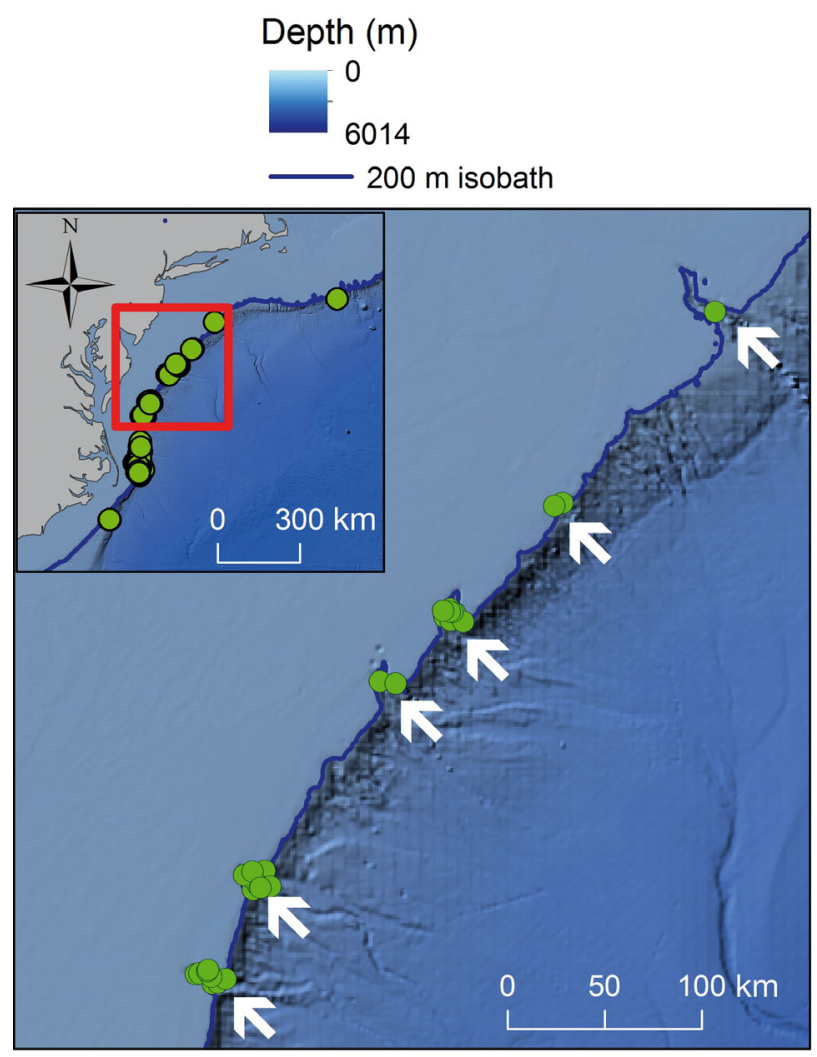

Fig. 7. Location of maximum first passage time (FPT) by week for all individual Globicephala macrorhynchus foraging in shelf break waters (inset: study area) relative to submarine canyons (indicated by arrows, from lower left to top right: Norfolk Canyon, Washington Canyon, Baltimore Canyon, Wilmington Canyon, Lindenkohl Canyon, and Hudson Canyon)

north of the SAB. The distribution of our tagged pilot whales was closely linked to steep bathymetric slopes occurring within their typical foraging depth range (approximately 200-1000 m depth). This may explain why the distribution of tagged pilot whales was focused north of Cape Lookout, since the continental shelf drops off much more gradually and steeper slopes are located in deeper waters south of this region (Fig. 1). Data from satellite tags deployed on 4 short-finned pilot whales in the SAB suggest that animals in the SAB show very different movement patterns than those to the north, with little or no association with the shelf break (A. J. Read unpubl. data). We suggest that the pilot whales occurring north of Cape Lookout might have developed specialized foraging behaviors for targeting steep bathymetric gradients in this region, and their latitudinal distribution may be limited by regions along the shelf break with steep gradients where this foraging strategy is effective.
Individual pilot whales varied considerably in the scale of their ARS behavior, though individuals consistently used shelf break and canyon habitats while foraging. Observed scales of ARS were generally small (mean: $24 \mathrm{~km}$ ) compared to scales of movement (Table 1), indicating that pilot whales focus their foraging efforts at a fine scale in spite of their highly mobile nature. In addition to showing considerable individual variability, cetacean foraging behavior can vary geographically, and foraging behavior can influence population structure (e.g. Lusseau et al. 2006, Hoelzel et al. 2007, Ansmann et al. 2012, Daura-Jorge et al. 2012, Mann et al. 2012). If the shelf break foraging behavior of short-finned pilot whales limits their distribution to waters of the MAB, this foraging specialization could limit interactions with pilot whales further south. Comparisons of the movements, foraging behavior, and habitat associations of short-finned pilot whales in the SAB and MAB are needed in order to assess whether there might be separate stocks of short-finned pilot whales in the US Atlantic EEZ, and to determine whether foraging behavior might play a role in maintaining stock structure. In addition to broad-scale geographical differences in foraging behavior, pilot whales have long-term social bonds which could lead to foraging specializations within social groups (Amos et al. 1993, Ottensmeyer \& Whitehead 2003, Mahaffy et al. 2015). Tracks from multiple individuals within different social groups are required to investigate how social structure might influence foraging behavior between groups of shortfinned pilot whales in the MAB.

The limited information on pilot whale diet in the northwest Atlantic suggests that short-finned pilot whales forage on pelagic cephalopods (e.g. Brachioteuthis riisei, Taonius pavo, Histioteuthis reversa; Mintzer et al. 2008), but the distribution of these prey species has not been well documented. Pilot whales may use steep bathymetric gradients and fine-scale variation in bottom topography along the shelf break as a physical barrier against which to herd prey, much like other cetaceans which herd prey against the surface (Würsig 1986, Vaughn et al. 2008). Submarine canyons occurring along the shelf break were used intensively by foraging short-finned pilot whales. Canyons provide important foraging areas for marine mammals (e.g. Schoenherr 1991, Hooker et al. 1999, Waring et al. 2001, Benoit-Bird et al. 2004, Croll et al. 2005, Rennie et al. 2009), and our telemetry data demonstrate the extent to which the foraging habitat of individual pilot whales was dominated by canyons. Like other types of abrupt topographies, canyons can create concentrations of lower 
trophic level species, and upwelling flow within canyons can influence the vertical and horizontal distribution of marine organisms (Allen et al. 2001, Bosley et al. 2004). Euphasiids and mesopelagic prey can be advected upward and towards canyon walls (Bosley et al. 2004), and upwelling that aggregates and advects prey into shallower waters is likely an important mechanism providing enhanced foraging opportunities for marine mammals (Schoenherr 1991, MacLeod \& Zuur 2005). Analyses of dive behavior will be useful for examining foraging behavior within and outside of canyons.

Shelf break canyons vary considerably in size, and previous studies have suggested that large canyons are likely to support larger numbers of cetaceans than smaller features (Wimmer \& Whitehead 2004). The largest canyon within our study area is Hudson Canyon, which is also the northernmost canyon targeted by foraging pilot whales in our study. Hudson Canyon clearly stands out in plots of pilot whale habitat use as a region of increased density (see the $75 \%$ KDE in Fig. 2), suggesting that pilot whales may travel north to forage within this large submarine canyon.

Submarine canyons contain a diversity of undersea habitats, support high densities of marine organisms, and are considered to be important conservation hotspots in marine environments (Vetter \& Dayton 1998, Hooker et al. 1999, Yen et al. 2004, Mortenson \& Buhl-Mortenson 2005, De Leo et al. 2010, Vetter et al. 2010). The Gully, a large submarine canyon off eastern Canada, was designated as a Marine Protected Area in 2004, due in large part to a small population of northern bottlenose whales Hyperoodon ampullatus occurring in this region and increasing threats due to oil and gas exploration and development (Whitehead et al. 1997, Gowans et al. 2000, Wimmer \& Whitehead 2004). Hudson Canyon was recently nominated as a national marine sanctuary due to its importance as habitat to a variety of marine organisms, and our results suggest that sanctuary designation in Hudson Canyon could protect important foraging habitat for short-finned pilot whales. However, pilot whales are highly mobile and regularly transit out of canyons and along shelf break regions throughout the MAB and thus conservation and management efforts for the species should include additional areas and measures in order to be effective.

Tagged short-finned pilot whales moved further north than expected, with 1 animal traveling into Canadian waters as far north as $42^{\circ} \mathrm{N}$ latitude, near the Northeast Channel, during August 2015. As far as we are aware, this is the first confirmed record of the species occurring in waters off eastern Canada, although short-finned pilot whales occur regularly in waters off western Canada (Stacey \& Baird 1993). Waters on the continental shelf of the northeast USA have experienced high rates of warming in the last few decades (Friedland \& Hare 2007, Belkin 2009, Pershing et al. 2015), and it is unclear whether our observations of short-finned pilot whales in more northerly waters represent a distributional shift in association with increases in water temperature, or whether limited observations with genetic samples confirming species identity in previous studies prevented a more complete understanding of shortfinned pilot whale range. Regardless, our results suggest that short-finned pilot whales regularly use habitats throughout the northeastern seaboard of the USA, where the majority of interactions between pilot whales and the US pelagic longline fishery occur (Garrison 2007). Movements and foraging behavior of tagged short-finned pilot whales indicate that this species is closely associated with the shelf break, except when foraging in offshore Gulf Stream waters where interactions with the US pelagic longline fishery are not observed (Garrison 2007). This constrained distribution suggests that spatial approaches to mitigating pilot whale-longline interactions with the US fishery may be feasible and merits further investigation.

Some of our tagged pilot whales periodically ventured from the Cape Hatteras region into distant pelagic waters, following Gulf Stream meanders before returning to the shelf break. These offshore movements into international waters suggest that pilot whales are potentially also overlapping with fisheries outside of US waters, and that interactions between pilot whales and longlines in the high seas could represent an additional source of mortality for the northwest Atlantic stock of short-finned pilot whales. At the present time it is unclear what triggers pilot whales to undertake movements into distant offshore waters, or what impels them to return to the shelf break. Of course, it is possible that the Gulf Stream foraging strategy we observed is simply a bias associated with the location of our tag deployments on the shelf break off Cape Hatteras. Tagging efforts in Cape Hatteras are ongoing and future deployments in other regions will help to investigate pilot whale movements in association with the Gulf Stream in more detail.

We found that the Cape Hatteras region is an important hotspot of short-finned pilot whale density and foraging habitat (Figs. $2 \& 7$ ). We selected the 
Cape Hatteras shelf break as the site for tag deployment due to the extremely high densities of pilot whales occurring there, and we found that tagged pilot whales returned to Cape Hatteras repeatedly during tag deployments. Off Cape Hatteras, cool, low-salinity waters of the MAB converge with warm, high-salinity waters of the SAB along the continental slope, creating a strong temperature and salinity front known as the Hatteras Front (Berger et al. 1995, Savidge 2002). The Hatteras region hosts an abundance of fish and upper trophic level predators (e.g. Magnuson et al. 1981, LaBrecque 2006, Mansfield et al. 2009), and likely creates enhanced foraging opportunities for pilot whales.

Our results demonstrate the foraging associations and highly mobile nature of short-finned pilot whales and emphasize the importance of shelf break systems and associated submarine canyons to the foraging habitat of deep-diving marine predators. Further, our results have implications for the management of short-finned pilot whales within the US Atlantic EEZ; our findings raise questions about the stock structure of short-finned pilot whales, and suggest that the shelf break and associated submarine canyons in this region should be the focus of conservation and management efforts for this species.

Acknowledgements. We are very grateful to Danielle Waples and Will Cioffi for their assistance during field work. Funding for telemetry field studies was provided by the US Fleet Forces Command through the Naval Facilities Engineering Command Atlantic and funding for the analysis of telemetry data was provided by the National Marine Fisheries Service (NMFS) through the Bycatch Reduction Engineering Program (award NA15NMF4720372 to L.H.T.). Tagging studies were authorized under NMFS permit 17086 to R.W.B. All research protocols were approved by the Institutional Animal Care and Use Committee at the Cascadia Research Collective.

\section{LITERATURE CITED}

Abend A, Smith T (1999) Review of the distribution of the long-finned pilot whale (Globicephala melas) in the North Atlantic and Mediterranean. NOAA Tech Memo NMFS-NE 117:22

Acha EM, Mianzan HW, Guerrero RA, Favero M, Bava J (2004) Marine fronts at the continental shelves of austral South America: physical and ecological processes. J Mar Syst 44:83-105

Aguilar Soto N, Johnson MP, Madsen PT, Díaz F, Domínguez I, Brito A, Tyack P (2008) Cheetahs of the deep sea: deep foraging sprints in short-finned pilot whales off Tenerife (Canary Islands). J Anim Ecol 77:936-947

Allen S, Vindeirinho C, Thomson R, Foreman MG, Mackas D (2001) Physical and biological processes over a submarine canyon during an upwelling event. Can J Fish Aquat Sci 58:671-684
Amos B, Schlotterer C, Tautz D (1993) Social structure of pilot whales revealed by analytical DNA profiling. Science 260:670-672

* Ansmann IC, Parra GJ, Chilvers BL, Lanyon JM (2012) Dolphins restructure social system after reduction of commercial fisheries. Anim Behav 84:575-581

Baird RW (2016) The lives of Hawai'i's dolphins and whales: natural history and conservation. University of Hawai'i Press, Honolulu, HI

* Baird RW, Dill LM (1995) Occurrence and behaviour of transient killer whales: seasonal and pod-specific variability, foraging behaviour, and prey handling. Can J Zool 73: 1300-1311

Baird RW, Borsani JF, Hanson MB, Tyack PL (2002) Diving and night-time behavior of long-finned pilot whales in the Ligurian Sea. Mar Ecol Prog Ser 237:301-305

* Belkin IM (2009) Rapid warming of large marine ecosystems. Prog Oceanogr 81:207-213

* Benoit-Bird KJ, Würsig B, Mfadden CJ (2004) Dusky dolphin (Lagenorhynchus obscurus) foraging in two different habitats: active acoustic detection of dolphins and their prey. Mar Mamm Sci 20:215-231

Berger T, Hamilton P, Weyland R, Blanton J, Boicort W, Churchill J, Watts R (1995) A physical oceanographic field program offshore North Carolina: final synthesis report. OCS Study MMS 94-0047. U.S. Department of the Interior, Minerals Management Service, Gulf of Mexico OCS Region, New Orleans, LA

Borkman DG, Smayda TJ (2009) Gulf Stream position and winter NAO as drivers of long-term variations in the bloom phenology of the diatom Skeletonema costatum 'species-complex' in Narragansett Bay, RI, USA. J Plankton Res 31:1407-1425

Bosley KL, Lavelle JW, Brodeur RD, Wakefield WW, Emmett RL, Baker ET, Rehmke KM (2004) Biological and physical processes in and around Astoria submarine Canyon, Oregon, USA. J Mar Syst 50:21-37

* Catard A, Weimerskirch H, Cherel Y (2000) Exploitation of distant Antarctic waters and close shelf-break waters by white-chinned petrels rearing chicks. Mar Ecol Prog Ser 194:249-261

* Cianfrani C, Le Lay G, Maiorano L, Satizábal HF, Loy A, Guisan A (2011) Adapting global conservation strategies to climate change at the European scale: the otter as a flagship species. Biol Conserv 144:2068-2080

* Colloca F, Carpentieri P, Balestri E, Ardizzone G (2004) A critical habitat for Mediterranean fish resources: shelfbreak areas with Leptometra phalangium (Echinodermata: Crinoidea). Mar Biol 145:1129-1142

Conversi A, Piontkovski S, Hameed S (2001) Seasonal and interannual dynamics of Calanus finmarchicus in the Gulf of Maine (Northeastern US shelf) with reference to the North Atlantic Oscillation. Deep-Sea Res II 48: 519-530

Croll DA, Marinovic B, Benson S, Chavez FP, Black N, Ternullo R, Tershy BR (2005) From wind to whales: trophic links in a coastal upwelling system. Mar Ecol Prog Ser 289:117-130

Curio E (1976) The ethology of predation. Zoophysiology and ecology, Vol 7. Springer-Verlag, New York, NY

* Daura-Jorge F, Cantor M, Ingram S, Lusseau D, SimõesLopes P (2012) The structure of a bottlenose dolphin society is coupled to a unique foraging cooperation with artisanal fishermen. Biol Lett 8:702-705

* De Leo FC, Smith CR, Rowden AA, Bowden DA, Clark MR 
(2010) Submarine canyons: hotspots of benthic biomass and productivity in the deep sea. Proc R Soc B 277: 2783-2792

* Douglas DC, Weinzierl RC, Davidson S, Kays R, Wikelski M, Bohrer G (2012) Moderating Argos location errors in animal tracking data. Methods Ecol Evol 3:999-1007

Estes J, Riedman M, Staedler M, Tinker M, Lyon B (2003) Individual variation in prey selection by sea otters: patterns, causes and implications. J Anim Ecol 72:144-155

Fauchald P (1999) Foraging in a hierarchical patch system. Am Nat 153:603-613

Fauchald P, Tveraa T (2003) Using first-passage time in the analysis of area-restricted search and habitat selection. Ecology 84:282-288

Fratantoni PS, Holzwarth-Davis T, Taylor MH (2015) Description of oceanographic conditions on the Northeast US Continental Shelf during 2014. US Dept Commerce, NEFSC Ref Doc 15-21, Woods Hole, MA

Freeman R, Dennis T, Landers T, Thompson D, Bell E, Walker M, Guilford T (2010) Black Petrels (Procellaria parkinsoni) patrol the ocean shelf-break: GPS tracking of a vulnerable procellariiform seabird. PLOS ONE 5: e9236

Friedland KD, Hare JA (2007) Long-term trends and regime shifts in sea surface temperature on the continental shelf of the northeast United States. Cont Shelf Res 27: 2313-2328

Gannon DP, Read AJ, Craddock JE, Fristrup KM, Nicolas JR (1997) Feeding ecology of long-finned pilot whales Globicephala melas in the western North Atlantic. Mar Ecol Prog Ser 148:1-10

Garrison LP (2007) Interactions between marine mammals and pelagic longline fishing gear in the US Atlantic Ocean between 1992 and 2004. Fish Bull 105:408-417

Genin A (2004) Bio-physical coupling in the formation of zooplankton and fish aggregations over abrupt topographies. J Mar Syst 50:3-20

Gowans S, Whitehead H, Arch JK, Hooker SK (2000) Population size and residency patterns of northern bottlenose whales (Hyperoodon ampullatus) using the Gully, Nova Scotia. J Cetacean Res Manag 2:201-210

Hayes SA, Josephson E, Maze-Foley K, Rosel PE (2017) US Atlantic and Gulf of Mexico marine mammal stock assessments - 2012. NOAA Tech Memo NMFS NE 241

Hazen EL, Jorgensen S, Rykaczewski RR, Bograd SJ and others (2013) Predicted habitat shifts of Pacific top predators in a changing climate. Nat Clim Change 3:234-238

*He R, Chen K, Fennel K, Gawarkiewicz G, McGillicuddy D Jr (2011) Seasonal and interannual variability of physical and biological dynamics at the shelfbreak front of the Middle Atlantic Bight: nutrient supply mechanisms. Biogeosciences 8:2935

Heide-Jørgensen MP, Bloch D, Stefansson E, Mikkelsen B, Ofstad LH, Dietz R (2002) Diving behaviour of longfinned pilot whales Globicephala melas around the Faroe Islands. Wildl Biol 8:307-313

*Herman AW, Sameoto DD, Longhurst AR (1981) Vertical and horizontal distribution patterns of copepods near the shelf break south of Nova Scotia. Can J Fish Aquat Sci 38:1065-1076

KHoelzel AR, Hey J, Dahlheim ME, Nicholson C, Burkanov V, Black N (2007) Evolution of population structure in a highly social top predator, the killer whale. Mol Biol Evol 24:1407-1415

*Hooker SK, Whitehead H, Gowans S (1999) Marine pro- tected area design and the spatial and temporal distribution of cetaceans in a submarine canyon. Conserv Biol 13:592-602

Jensen FH, Perez JM, Johnson M, Soto NA, Madsen PT (2011) Calling under pressure: short-finned pilot whales make social calls during deep foraging dives. Proc R Soc B 278:3017-3025

Kappes MA, Shaffer SA, Tremblay Y, Foley DG and others (2010) Hawaiian albatrosses track interannual variability of marine habitats in the North Pacific. Prog Oceanogr 86:246-260

Kareiva P, Odell G (1987) Swarms of predators exhibit 'preytaxis' if individual predators use area-restricted search. Am Nat 130:233-270

LaBrecque EA (2006) Assessing the importance of frontal zones on the distribution of upper trophic level predators off Cape Hatteras. MEM thesis, Duke University, Durham, NC

Levin SA (1992) The problem of pattern and scale in ecology: the Robert H. MacArthur award lecture. Ecology 73: 1943-1967

* Lewison RL, Crowder LB, Read AJ, Freeman SA (2004) Understanding impacts of fisheries bycatch on marine megafauna. Trends Ecol Evol 19:598-604

* Lusseau D, Wilson B, Hammond PS, Grellier K and others (2006) Quantifying the influence of sociality on population structure in bottlenose dolphins. J Anim Ecol 75: $14-24$

* Mackas DL, Kieser R, Saunders M, Yelland DR, Brown RM, Moore DF (1997) Aggregation of euphausiids and Pacific hake (Merluccius productus) along the outer continental shelf off Vancouver Island. Can J Fish Aquat Sci 54: 2080-2096

*MacLeod CD, Zuur AF (2005) Habitat utilization by Blainville's beaked whales off Great Abaco, northern Bahamas, in relation to seabed topography. Mar Biol 147: $1-11$

Magnuson JJ, Harrington CL, Stewart DJ, Herbst GN (1981) Responses of macrofauna to short-term dynamics of a Gulf Stream front on the Continental Shelf. In: Richards FA (ed) Coastal upwelling. Coastal and estuarine sciences, Vol 1. American Geophysical Union, Washington, DC, p 441-448

*Mahaffy SD, Baird RW, McSweeney DJ, Webster DL, Schorr GS (2015) High site fidelity, strong associations, and long-term bonds: short-finned pilot whales off the island of Hawai'i. Mar Mamm Sci 31:1427-1451

*Mann J, Stanton MA, Patterson EM, Bienenstock EJ, Singh LO (2012) Social networks reveal cultural behaviour in tool-using dolphins. Nat Commun 3:980

*Mansfield KL, Saba VS, Keinath JA, Musick JA (2009) Satellite tracking reveals a dichotomy in migration strategies among juvenile loggerhead turtles in the Northwest Atlantic. Mar Biol 156:2555

* Mate BR, Lagerquist BA, Winsor M, Geraci J, Prescott JH (2005) Notes: movements and dive habits of a satellitemonitored longfinned pilot whale (Globicephala melas) in the Northwest Atlantic. Mar Mamm Sci 21:136-144

* Mei Z, Chen M, Li Y, Huang SL and others (2017) Habitat preference of the Yangtze finless porpoise in a minimally disturbed environment. Ecol Modell 353:47-53

Mintzer VJ, Gannon DP, Barros NB, Read AJ (2008) Stomach contents of mass-stranded short-finned pilot whales (Globicephala macrorhynchus) from North Carolina. Mar Mamm Sci 24:290-302 
Moore SE (2008) Marine mammals as ecosystem sentinels. J Mammal 89:534-540

Moors-Murphy HB (2014) Submarine canyons as important habitat for cetaceans, with special reference to the Gully: a review. Deep Sea Res II 104:6-19

Mortensen PB, Buhl-Mortensen L (2005) Deep-water corals and their habitats in The Gully, a submarine canyon off Atlantic Canada. In: Freiwald A, Murray Roberts J (eds) Cold-water corals and ecosystems. Springer, Berlin, p $247-277$

Munk P, Larsson PO, Danielssen D, Moksness E (1995) Larval and small juvenile cod Gadus morhua concentrated in the highly productive areas of a shelf break front. Mar Ecol Prog Ser 125:21-30

Nowacek DP (2002) Sequential foraging behaviour of bottlenose dolphins, Tursiops truncatus, in Sarasota Bay, FL. Behaviour 139:1125-1145

Nye JA, Joyce TM, Kwon YO, Link JS (2011) Silver hake tracks changes in Northwest Atlantic circulation. Nat Commun 2:412

OKkonen SR, Ashjian CJ, Campbell RG, Clarke JT, Moore SE, Taylor KD (2011) Satellite observations of circulation features associated with a bowhead whale feeding 'hotspot' near Barrow, Alaska. Remote Sens Environ 115: 2168-2174

Ottensmeyer CA, Whitehead H (2003) Behavioural evidence for social units in long-finned pilot whales. Can J Zool 81: 1327-1338

*Pendoley KL, Schofield G, Whittock PA, Ierodiaconou D, Hays GC (2014) Protected species use of a coastal marine migratory corridor connecting marine protected areas. Mar Biol 161:1455-1466

* Pershing AJ, Alexander MA, Hernandez CM, Kerr LA and others (2015) Slow adaptation in the face of rapid warming leads to collapse of the Gulf of Maine cod fishery. Science 350:809-812

* Pinaud D, Weimerskirch H (2005) Scale-dependent habitat use in a long-ranging central place predator. J Anim Ecol 74:852-863

* Planque B, Taylor AH (1998) Long-term changes in zooplankton and the climate of the North Atlantic. ICES J Mar Sci 55:644-654

Q Quick NJ, Isojunno S, Sadykova D, Bowers M, Nowacek DP, Read AJ (2017) Hidden Markov models reveal complexity in the diving behaviour of short-finned pilot whales. Sci Rep 7:45765

Rendell L, Whitehead H (2001) Culture in whales and dolphins. Behav Brain Sci 24:309-324

Rennie S, Hanson C, McCauley R, Pattiaratchi C and others (2009) Physical properties and processes in the Perth Canyon, Western Australia: links to water column production and seasonal pygmy blue whale abundance. J Mar Syst 77:21-44

Robinson P, Tremblay Y, Crocker D, Kappes M and others (2007) A comparison of indirect measures of feeding behaviour based on ARGOS tracking data. Deep-Sea Res II 54:356-368

Rone BK, Pace RM III (2012) A simple photograph-based approach for discriminating between free-ranging longfinned (Globicephala melas) and short-finned (G. macrorhynchus) pilot whales off the east coast of the United States. Mar Mamm Sci 28:254-275

Ryan JP, Chavez FP, Bellingham JG (2005) Physical-biological coupling in Monterey Bay, California: topographic influences on phytoplankton ecology. Mar Ecol Prog Ser 287:23-32

Sargeant B, Mann J, Berggren P, Krützen M (2005) Specialization and development of beach hunting, a rare foraging behavior, by wild bottlenose dolphins (Tursiops sp.). Can J Zool 83:1400-1410

* Savidge DK (2002) Wintertime shoreward near-surface currents south of Cape Hatteras. J Geophys Res 107:1-18

* Schoenherr JR (1991) Blue whales feeding on high concentrations of euphausiids around Monterey Submarine Canyon. Can J Zool 69:583-594

* Springer AM, McRoy CP, Flint MV (1996) The Bering Sea green belt: shelf-edge processes and ecosystem production. Fish Oceanogr 5:205-223

Stacey P, Baird RW (1993) Status of the short-finned pilot whale, Globicephala macrorhynchus, in Canada. Can Field Nat 107:481-489

Suryan RM, Sato F, Balogh GR, Hyrenbach KD, Sievert PR, Ozaki K (2006) Foraging destinations and marine habitat use of short-tailed albatrosses: a multi-scale approach using first-passage time analysis. Deep-Sea Res II 53: 370-386

Taylor BL, Baird R, Barlow J, Dawson SM and others (2008) Globicephala melas. IUCN Red List 2008:e.T9250A 12975001

Taylor BL, Baird R, Barlow J, Dawson SM and others (2011) Globicephala macrorhynchus. IUCN Red List 2011: e.T9249A12972356

Vaughn RL, Würsig B, Shelton DS, Timm LL, Watson LA (2008) Dusky dolphins influence prey accessibility for seabirds in Admiralty Bay, New Zealand. J Mammal 89: 1051-1058

V Vetter E, Dayton P (1998) Macrofaunal communities within and adjacent to a detritus-rich submarine canyon system. Deep-Sea Res II 45:25-54

V Vetter EW, Smith CR, De Leo FC (2010) Hawaiian hotspots: enhanced megafaunal abundance and diversity in submarine canyons on the oceanic islands of Hawaii. Mar Ecol 31:183-199

*Waring G, Hamazaki T, Sheehan D, Wood G, Baker S (2001) Characterization of beaked whale (Ziphiidae) and sperm whale (Physeter macrocephalus) summer habitat in shelf-edge and deeper waters off the northeast US. Mar Mamm Sci 17:703-717

*Whitehead H, Gowans S, Faucher A, Mccarrey SW (1997) Population analysis of northern bottlenose whales in the Gully, Nova Scotia. Mar Mamm Sci 13:173-185

* Wimmer T, Whitehead H (2004) Movements and distribution of northern bottlenose whales, Hyperoodon ampullatus, on the Scotian Slope and in adjacent waters. Can J Zool 82:1782-1794

Würsig B (1986) Delphinid foraging strategies. In: Schusterman R, Thomas JA, Wood FG (eds) Dolphin cognition and behavior: a comparative approach. Lawrence Erlbaum Associates, Hillsdale, NJ, p 347-359

*Yen PP, Sydeman WJ, Hyrenbach KD (2004) Marine bird and cetacean associations with bathymetric habitats and shallow-water topographies: implications for trophic transfer and conservation. J Mar Syst 50:79-99

* Young J, Bradford R, Lamb T, Clementson L, Kloser R, Galea $\mathrm{H}$ (2001) Yellowfin tuna (Thunnus albacares) aggregations along the shelf break off south-eastern Australia: links between inshore and offshore processes. Mar Freshw Res 52:463-474

Submitted: May 11, 2017; Accepted: October 16, 2017

Proofs received from author(s): December 3, 2017 